\title{
Analysis of Factors Affecting Adoption of Mobile Banking Application in Indonesia
}

\author{
Mufingatun $^{1 *}$, Budi Prijanto ${ }^{2}$ \\ 1, 2 Gunadarma University \\ 1'fiaaopi@gmail.com, ${ }^{2}$ karami@staff.gunadarma.ac.id \\ ${ }^{*}$ Corresponding author
}

\begin{abstract}
The development of information technology makes banking provide mobile banking service applications in Indonesia as an easy, convenient and fast service. However, there are still many customers who do not have a mobile banking account. In addition, the use of currency is still in demand by society. Therefore, the purpose of this study is to determine the factors that influence consumer acceptance in the context of mobile banking applications. This study uses the Unified Theory of Acceptance and Use of Technology (UTAUT2) model which is modified by adding the variable perceived credibility and perceived self-efficacy. This research model was tested using 205 respondents from online surveys in Jabodetabek, Indonesia. Data were analyzed using Partial Least Square (PLS). Performance expectancy, effort expectancy, social influence has a significant effect on behavioral intention. Performance expectancy is the factor that most influences the behavior intention. Behavioral intention, facilitating condition and habit has a significant effect on reuse behavior.
\end{abstract}

Keywords: mobile banking, UTAUT2, perceived credibility, perceived self-efficacy

\begin{abstract}
Abstrak
Perkembangan teknologi informasi menjadikan banking menyediakan aplikasi layanan mobile banking di Indonesia sebagai layanan yang mudah, nyaman dan cepat. Namun demikian, masih banyak nasabah yang belum memiliki rekening mobile banking. Selain itu, penggunaan mata uang masih diminati oleh masyarakat. Oleh karena itu, tujuan penelitian ini adalah untuk mengetahui faktor-faktor yang mempengaruhi penerimaan konsumen dalam konteks aplikasi mobile banking. Penelitian ini menggunakan model Unified Theory of Acceptance and Use of Technology (UTAUT2) yang dimodifikasi dengan menambahkan variabel perceived credibility dan perceived self-efficacy. Model penelitian ini diuji dengan menggunakan 205 responden dari survei online di Jabodetabek, Indonesia. Data dianalisis menggunakan Partial Least Square (PLS). Harapan kinerja, harapan usaha, pengaruh sosial berpengaruh signifikan terhadap niat berperilaku. Harapan kinerja merupakan faktor yang paling mempengaruhi niat berperilaku. Niat perilaku, kondisi fasilitasi dan kebiasaan berpengaruh signifikan terhadap perilaku penggunaan kembali.
\end{abstract}

Kata kunci: mobile banking, UTAUT2, persepsi kredibilitas, persepsi self-efficacy

\section{Cara Mengutip:}

Mufingatun, Prijanto, B., (2020). Analysis of Factors Affecting Adoption of Mobile Banking Application in Indonesia. Esensi: Jurnal Bisnis dan Manajemen. Vol. 10 (1) : 31-44. DOI: 10.15408/ess.v10i1.13972 


\section{INTRODUCTION}

The development of information technology improves mobile devices such as smartphones, notebooks, netbooks and tablet computers with a network of 3G and 4G internet connections that support. Indonesia's population of 251 million is the country with the largest smartphone users in the world (Rema and Djoko, 2016). According to data from Emarketer in 2014, it is estimated that by 2018 the number of active smartphone users in Indonesia will be more than 100 users. Where this number, Indonesia is the country with the fourth largest active smartphone users in the world after China, India and America (Indah, 2015).

The use of mobile devices is increasingly rapid making the media to make transactions. This provides banking business opportunities as a driver to provide mobile banking service applications in Indonesia. With mobile banking, the banking sector seeks to provide services that are easy, convenient, fast, anytime and anywhere for customers to conduct financial transactions and access information securely, in addition to connecting the bank with its customers through the internet.

In Indonesia, the practice of internet banking was first introduced by BII (PT Bank Internasional Indonesia, Tbk) in 1988 with an application called BII Internet Banking. After that followed by BCA (PT Bank Central Asia, Tbk) on March 20, 2001, with the KlikBCA application, then on April 26, 2001, also Bank Niaga (PT Bank Niaga, Tb) launched an application called Niaga Global@cess. The use of mobile banking in addition to facilitating customer transactions as well as information technology resources is an important factor in influencing the efficiency and effectiveness of banking business. With the presence of mobile banking, this can happen because mobile banking can reduce human error by bank tellers when processing cash transactions.

According to the results of the MARS Indonesia survey institute in 2013, bank customers' penetration or mobile banking usage rates reached $41.2 \%$. There are still around $58.8 \%$ of customers who provide statements that do not have a mobile banking account. The survey results increased by $23.6 \%$ compared to the results of the survey in 2008, namely penetration of mobile banking accounts for only 17.6\% (MARS Indonesia Newsletter, 2013). However, according to the research institute Microsave, it was explained that internet users for financial services in Indonesia were only $0.73 \%$ of the total cellular phone users, the figure was relatively small compared to Malaysia, which was $5.79 \%$ (Tempo, 2016).

This can happen because the Indonesian people still like using cash as their transactions Current technological developments cannot directly change people's lifestyles (Tarhini et al., 2016). One of the factors that make people prefer cash transactions is that they are not yet accustomed to using smartphones and that concerns about security factors are still a basic consideration for someone to make non-cash transactions (Nugroho et al., 2017). According to Pertiwi and Dodi (2017) one of the causes of the number of customers who have not adopted mobile banking even though many benefits that will be obtained is the lack of socialization by the bank. Hartono in Pertiwi and Dodik (2017) states that there are still many who experience failure in the application of an information system even though the quality of the system technique has increased. 
The data taken is for customers who have used the mobile banking application in the area Jabodetabek (Jakarta, Bogor, Depok, Tangerang and Bekasi) Indonesia. Data collection in the area Jabodetabek is because is one of the biggest internet users in Indonesia. According to the results of a survey conducted by the Indonesian Internet Service Providers Association (APJII) in 2016, the majority of internet users in Indonesia were on Java with a total user of $86,339,350$ users or around $65 \%$ of the total internet usage (APJII, 2016). This is a reference for researchers that the Jabodetabek area is representative in reflecting the interests and behavior of using mobile banking.

Therefore, it is necessary to know the acceptability of mobile banking applications from the user's perspective so that they can be used as a reference for customers who do not have and use mobile banking applications, besides that it can also be used as a means to improve organizational performance, especially in banking institutions. This study is based on the identification of factors in the Unified Theory of Acceptance and Use of Technology (UTAUT2) model with the addition of variables perceived credibility and perceived self-efficacy.

The objectives are (1) to find out and analyze modifications to the UTAUT2 model that have been proposed in predicting the adoption of an information system, especially mobile banking. (2) To find out and analyze the influence of performance expectancy, effort expectancy, social influence, price/value, hedonic motivation, and perceived credibility variables on behavioral intention to use mobile banking in Indonesia. (3) To find out and analyze the influence of behavioral intention, facilitating condition, habit and perceived self-efficacy on reuse behavior to use mobile banking in Indonesia. (4) Provide recommendations from the results of analysis according to the data obtained as an increase in mobile banking services to users.

According to Otoritas Jasa Keuangan (2015), the definition of mobile banking is a service that allows bank customers to conduct banking transactions via a smartphone. Mobile banking offers convenience when compared to SMS banking because customers do not need to remember the SMS message format that will be sent to the bank and the SMS banking destination number. The mobile banking service is contained in a Bank Indonesia Regulation No.9/15/PBI/2007 the Year 2007 concerning Application of Risk Management in the Use of Information Technology by Commercial Banks and also contained in UU No. 11 the Year 2008 about Information and Electronic Transactions (Pertiwi dan Ariyanto, 2017).

The Bank continues to renew its technology and improve so that it can reach all of their customers. One of the advantages of using mobile banking is that people in rural or remote areas can also access mobile banking easily, whenever needed (Nayak, et al., 2014). Then another advantage is the confidentiality of user IDs that are not easily known by other parties (Pertiwi and Ariyanto, 2017).

Unified Theory of Acceptance and Use of Technology 2 (UTAUT2) is a model of the results of the development of research conducted by Venkantesh et al., (2012). The use of UTAUT2 in this study based on empirical evidence has been shown to provide an overview of the user's intent to use information systems and individual usage behaviors (Bhimasta, 2017). The purpose of the UTAUT2 model is (1) to identify three important constructs of research in the use and acceptance of both public and consumers, (2) to change some of 
the existing relationships in the concept of the UTAUT model, and (3) to introduce new relationships (Venkantesh et al., 2012).

Performance expectations are similar to the perceived usefulness of TAM / TAM2, the relative advantage of IDT, and outcome expectations of SCT (Kit et al., 2014). Performance expectations reflect the extent to which someone believes that using mobile banking will provide benefits in carrying out banking activities (Venkantesh et al., 2003). Performance expectations are expected to be one of the most important factors that directly affect acceptance intentions (Baptista and Tiago, 2015). Previous research (Nugroho et al., 2017; AbuShanabet al., 2010; Venkantesh.et al., 2012; Azis and Kamal, 2016) explained that performance expectations are strong variables that influence interest in using mobile banking. Accordingly, this study hypothesis:

$\mathrm{H}_{1}$ : Performance expectancy significantly affect behavioral intention to use mobile banking.

In UTAUT, business expectations have a perceived easy to use from TAM, complexity from MPCU and ease of use at IDT (Venkantesh et al., 2003). According to Rema and Djoko (2016) that business expectations or business expectations according to UTAUT explain the user's perceptions of the level of ease associated with the use of a system so that it relates to the ease of learning in using or skilled in using mobile banking. When users feel that mobile banking is easy to use and doesn't require much effort, they have high expectations for the expected performance (Nugroho et al., 2017). In previous studies, they are (Rema and Djoko, 2016; Abushanab et al, 2010; Foon and Fah, 2011; Kit et al., 2014; Azis and Kamal, 2016) have the results of business expectations affect the interest in using mobile banking. Accordingly, this study hyphothesis:

$\mathrm{H}_{2}$ : Effort expectancy significantly affects behavioral intention to use mobile banking.

Social influence on UTAUT2 is similar to subjective norms of the TRA, TAM2, TBP / DTBP models, TAM + TPB, social factors of MPCU, and the image of IDT. According to Nugroho et al., (2017), the use of certain technologies is influenced by environmental factors such as the opinions of friends and family who use the technology, with a positive opinion or support it will encourage users to start using the technology. Previous research (Yu, 2012; AbuShanab et al.,2010; Foon and Fah, 2011; and Azis and Kamal, 2016) also explained that social influence has an influence on the interest in using mobile banking. Accordingly, this study hypothesis:

$\mathrm{H}_{3}$ : Social influence significantly affects behavioral intention to use mobile banking.

Baptista and Taigo (2015) add factors that include, for example, data service operator fees, namely mobile Internet, device fees, service fees and transaction fees, if necessary. When consumers receive the benefits of using mobile banking they feel that they are greater than the costs incurred, consumers tend to feel compelled to use the interest to use mobile banking regularly (Nugroho et al., 2017). Price value variables influence interest in using technology to adopt mobile banking (Pertiwi and Arianto, 2017; Baptista and Taigo , 2015 there are similar studies with various technologies such as internet banking (Gaitan et al., 2015), mobile payments (Nugroho et al., 2017), e-commerce (Azis and Kamal, 2016) and mobile applications (Kit et al, 2014). Research conducted by Gaitan et al., 2015) states that the price value affects the interest in using technology. Accordingly, this study hypothesis: 
$\mathrm{H}_{4}$ : Price/value significantly affects behavioral intention to use mobile banking.

Hedonic motivation refers to the level of pleasure or pleasure gained from using mobile banking (Venkantesh et al., 2012). Research conducted by Kit et al (2014) states that hedonic motivation has a positive effect on interest in using mobile banking by referring to pleasant user experience or pleasure when using technology-based applications, the use of technology is driven by aspirations to engage in fun and entertaining activities. Previous studies (Magni, Taylor, and Venkantesh, 2010; and Kit, et al., 2014) state that hedonic motivation influences interest in using mobile banking. Accordingly, this study hypothesis: $\mathrm{H}_{5}$ : Hedonic motivation significantly affects behavioral intention to use mobile banking.

The research conducted by Azis and Kamal (2016) in the context of e-commerce, habits are shown to know consumer habits in using the internet to shop online in everyday life. Habit is one of the key constructs and explains the use directly and indirectly through intention to use (Gaitan et al., 2015). In addition, Lewis et al. (2013) found that habits have a positive influence on the behavior of technology use in the classroom. Previous research (Gaitan et al., 2015; Kit et al., 2014; Azis and Kamal, 2016; Baptista and Tiago, 2015; and Lewis et al., 2013) explained that habits have a positive influence on the behavior of using mobile banking. Taken the above together, this study hyphothesis :

$\mathrm{H}_{6}$ : Habit significantly affects reuse behavior of using mobile banking

Facilitating conditions are similar to perceived behavioral control from TPB, TPB + TAM, conditions that facilitate the MPCU and compatibility of IDT (Yu, 2012). Safety is also needed, users who have access to a range of favourable facilitation conditions, such as the online mobile banking, demo or online chat tutorial, users will have a greater intention to use mobile banking (Baptista and Tiago, 2015). Yu, 2012; Nugroho et al., 2017; Foon and Fah, 2011; and Tarhini et al., 2015) stated that facilitating conditions have a positive effect on the behavior of mobile banking usage. Taken the above together, this study hyphothesis : $\mathrm{H}_{7}$ : Facilitating condition significantly affects reuse behavior of using mobile banking

Variable additions aim to ascertain what factors greatly influence users to adopt mobile banking (Yu, 2012). Some studies that discuss the adoption of mobile banking have discussed that users will refuse or refuse to use mobile banking for various reasons for perceived risk (Riquelme and Rios, 2010; Natarjan et al., 2010) or perceived credibility (Luarn and Lin, 2005). Risk perception is also a very important consideration in acquiring new technologies or services (Laforet and Lin, 2005). Some studies have used perceptions of credibility not only in the context of mobile banking (Luarn and Lin, 2005; Riquelme, 2010; Yu, 2012), internet banking (Wang et al, 2003; Tarhini et al. 2015) and mobile payment (Nugroho et al., 2017). Based on previous research, the credibility of this research is to represent individual security, privacy, risk and trust regarding the use of mobile banking, as in Yu's (2012) study. Previous research (Yu, 2012; Tarhini, 2015; Jeong and Yoon, 2013 and Abuzwida et al., 2017) stated that perceptions of credibility had a positive effect on interest in using mobile banking. Taken the above together, this study hypothesis:

$\mathrm{H}_{8}$ : Perceived credibility significantly affects behavioral intention to use mobile banking

According to Brown et al. (2003), the perception of self-efficacy is not a direct determinant in influencing user behavior in adopting mobile banking. However, several 
studies that discuss mobile banking (Luarn and Lin, 2005; Sripalawat et al., 2010; Yu, 2012) support the perception of self-efficacy as a determinant in influencing user behavior towards mobile banking adoption. Another factor that significantly influences mobile banking adoption is self-efficacy (Jeong and Yoon, 2013). Luar and Lain (2005) states that the perception of self-efficacy has a positive influence on the perceived ease of users and intentions in using cellular services. And according to Nair and Fassal (2017), the perception of self-efficacy has a positive effect on the usefulness that will be felt. Previous research (Yu, 2012; AbuShanab, Pearson and Setterstom, 2010; Jeong and Yoon, 2013; Nair and Fassal, 2017 and Sripalawat et al., 2010) states that perceptions of self-efficacy influence the behavior of using mobile banking. Taken the above together, this study hyphothesis :

$\mathrm{H}_{9}$ : Perceived self-efficacy significantly affects reuse behavior of using mobile banking.

\section{METHOD}

The type of data in this study is the user wants to use mobile banking for transactions and other financial activities, while user behavior is used to explain the intensity of users in using mobile banking everyday (Azis and Kamal, 2016). The relationship between behavioral intention and using behavior in mobile banking adoption can be stated in the hypothesis as follows:

H10 : Behavioral intention significantly affects reuse behavior of using mobile banking.

Figure 1. Research Model

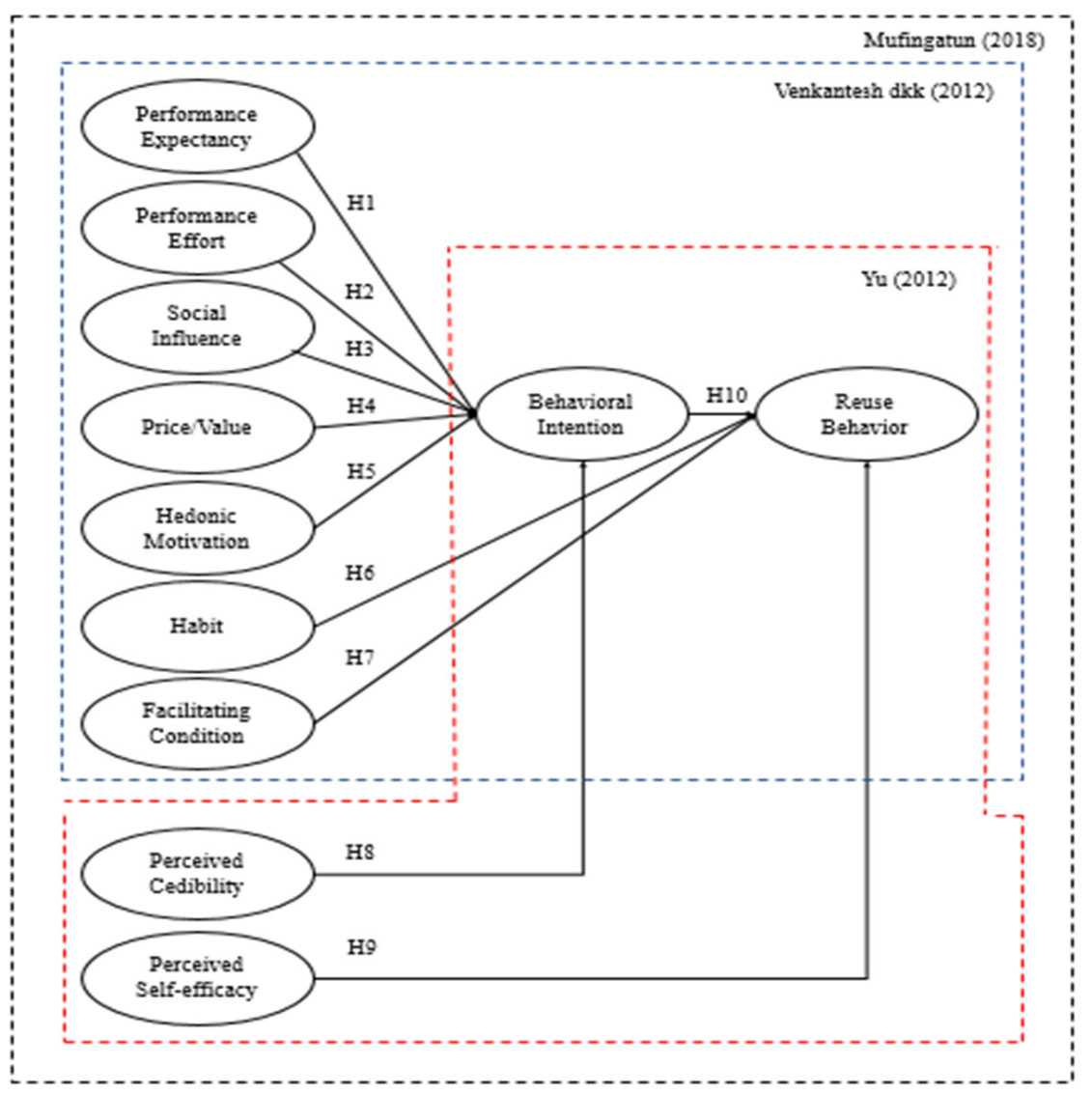


Based on the study of literature, as well as information on data from research, research models are primary data derived from respondents' answers to the questionnaire distributed. The criteria of respondents in this study are bank customers who use mobile banking in the Jabodetabek, Indonesia.

The population in this study is bank customers who use mobile banking in Jabodetabek, Indonesia. The sampling technique used in this study was nonprobability sampling with sampling techniques namely convenience sampling. Based on the process carried out, 205 respondents were following the criteria.

This study uses the Partial Least Square (PLS) approach. PLS is an equation model of Structural Equation Modeling (SEM) based on components or variants. PLS is a multivariate statistical technique that makes comparisons between multiple dependent variables and multiple independent variables (Jogiyanto, 2009). This study uses the help of Smart PLS software ver. 3.2.7.

\section{RESULT AND DISCUSSION}

In this research, thirty samples were tested to be tested on large samples. According to Latan and Ghozali (2012), outer models with reflexive indicators are evaluated through convergent validity and discriminant validity from constructing indicators, as well as reliability, namely composite reliability and Cronbach alpha for the indicator block. In testing the convergent validity in the first literacy three variables must be eliminated because $<0.70$, the indicators SI4, FC1 and FC2, then do the test again. The second literacy result states that all indicators have a value $>0.70$ so that they can proceed to the next test. In discriminant validity, the results of cross loading estimation show that the construct correlation value with the indicator is greater than the value of the correlation with other constructs.

The construct reliability test is stated to be reliable if the composite reliability and Cronbach alpha values are greater than 0.70 (Latan and Ghozali, 2012). From the results of reliability, the Cronbach's alpha and composite reliability values for all constructs are above the value of 0.70 .

According to Hass and Lehner (2009), the path coefficient values in the range of -0.1 to 0.1 are considered insignificant, a value greater than 0.1 is a significant value and is directly proportional, and a value smaller than $-0,1$ is a significant value and inversely proportional. The next consideration is to use a significance value, minimal at $\alpha=0.05$ so that it is considered significant if the value of P-value is less than 0.05 . Therefore, the hypothesis is accepted if the path coefficient value is greater than 0.0 and the P-value is smaller than 0.05 .

So that it can be concluded that out of the ten hypotheses proposed in this study there are four rejected hypotheses $\left(\mathrm{H}_{4}, \mathrm{H}_{5}, \mathrm{H}_{8}\right.$, dan $\left.\mathrm{H}_{9}\right)$ six hypotheses accepted there are $\mathrm{H}_{1}, \mathrm{H}_{2}, \mathrm{H}_{3}, \mathrm{H}_{6}, \mathrm{H}_{7}$, dan $\mathrm{H}_{10}$.

Based on the results of the study indicate that expectancy performance (PE) based on the significance test can be interpreted that performance expectancy (PE) has a significant positive effect on behavioral intention (BI). This can be seen from the value of 
p-values which are less than 0.05, which is 0.002 . According to Venkantesh et al., (2003) perfomance expectancy is a strong predictive variable from the use of information systems. In Yu's research. (2012) show that performance expectancy affects consumer intentions in adopting mobile banking. The results of this study are also in accordance with the research conducted by Nugroho et al (2017), AbuShanab, Pearson and Setterstom (2010), Venkantesh. Dkk (2012), Azis and Kamal (2016), Pertiwi and Ariyanto (2017), Yu (2012), Foon and Fah (2011), Gaitan et al (2015), Tarhini, et al. (2015), Baptista and Taigo (2015) and Kit, et al. (2014).

Table 1. Result of Adj. R-Square, $Q^{2}$ and GoF Test

\begin{tabular}{|c|c|c|c|c|}
\hline Test & & & Estimate & Result \\
\hline Adj. R-Square & $\rightarrow$ & $\mathrm{BI}$ & 0.405 & $\begin{array}{l}\text { The variables PE, EE, SI, PV, and PC are able to } \\
\text { explain } 40.5 \% \text {. The rest of } 59.5 \% \text { is influenced by } \\
\text { other factors. }\end{array}$ \\
\hline Adj. R-Square BI & $\rightarrow$ & USE & 0.336 & $\begin{array}{l}\mathrm{BI}, \mathrm{H}, \mathrm{FC} \text { and PSE variables are able to explain } \\
33.6 \% \text {. The remaining } 66.4 \% \text { is influenced by other } \\
\text { factors. }\end{array}$ \\
\hline Prediticve Relevance $\mathrm{Q}^{2}$ & $\rightarrow$ & $\mathrm{BI}$ & 0.262 & $\begin{array}{l}\text { The variables } \mathrm{PE}, \mathrm{EE}, \mathrm{SI}, \mathrm{PV} \text {, and } \mathrm{PC} \text { are able to } \\
\text { predict the } \mathrm{BI} \text { value of } 26.2 \% \text {. }\end{array}$ \\
\hline Prediticve Relevance $\mathrm{Q}^{2} \mathrm{BI}$ & $\rightarrow$ & USE & 0.197 & $\begin{array}{l}\text { BI, H, FC and PSE variables are able to predict USE } \\
\text { values of } 19.7 \% \text {. }\end{array}$ \\
\hline GoF & & & 0.522 & $\begin{array}{l}\text { The overall model is said to be fit because } 0.522> \\
0.36 \text {. }\end{array}$ \\
\hline
\end{tabular}

Source : SmartPLS Output, Data Processed

Based on the results of the study, effort expectancy (EE) has a significant positive effect on behavioral intention (BI) . This can be seen from the value of $p$-values which are less than 0.05, which is 0.002. According to Nugroho et al (2017) stated that when users feel that mobile banking is easy to use and does not require much effort, then they have high expectations for the expected performance. The results of this study are in line with the results of Rema and Djoko (2016), Abushanab et al (2010), Foon and Fah (2011), Kit et al (2014), and Azis and Kamal (2016).

Based on the results of the study indicate that social influence (SI) has a significant positive effect on behavioral intention (BI). This can be seen from the value of p-values which are less than 0.05 , which is 0.017 . This shows that with the environment of customers who tend to use mobile banking it will affect them to use mobile banking, not from their family or friends who suggest but they have seen the convenience felt by people who have used it, so that it can help increase productivity. Social influence is an influential variable that is natural because a very large environmental influence encourages someone to use technology (Azis and Kamal, 2016). This result is in line with Yu (2012), AbuShanab et al (2010), Foon and Fah (2011) and Azis and Kamal (2016). 
Table 2. Test Results on the Research Model

\begin{tabular}{clccc}
\hline Hyphothesis & \multicolumn{1}{c}{ Influence } & Path Coefficient & P Values & Result \\
\hline $\mathrm{H}_{1}$ & $\begin{array}{l}\text { Performance Expectancy } \rightarrow \text { Behavioral } \\
\text { Intention }\end{array}$ & 0.230 & 0.002 & Significant \\
$\mathrm{H}_{2}$ & Effort Expectancy $\rightarrow$ Behavioral Intention & 0.218 & 0.002 & Significant \\
$\mathrm{H}_{3}$ & Social Influence $\rightarrow$ Behavioral Intention & 0.137 & 0.017 & Significant \\
$\mathrm{H}_{4}$ & Price / Value $\rightarrow \quad$ Behavioral Intention & 0.113 & 0.093 & No Significant \\
$\mathrm{H}_{5}$ & Hedonic Motivation $\rightarrow$ Behavioral Intention & 0.105 & 0.198 & No Significant \\
$\mathrm{H}_{6}$ & Habit $\rightarrow$ Reuse Behavior & 0.171 & 0.020 & Significant \\
$\mathrm{H}_{7}$ & Facilitating Condition $\rightarrow$ Reuse Behavior & 0.180 & 0.014 & Significant \\
$\mathrm{H}_{8}$ & Perceived Credibility $\rightarrow$ Behavioral Intention & 0.105 & 0.118 & No Significant \\
$\mathrm{H}_{9}$ & Perceived Self-Efficacy $\rightarrow$ Reuse Behavior & 0.035 & 0.657 & No Significant \\
$\mathrm{H}_{10}$ & Behavioral Intention $\rightarrow$ Reuse Behavior & 0.370 & 0.000 & Significant \\
\hline
\end{tabular}

Source : SmartPLS Output, Data Processed

Based on the results of the study indicate that price / value (PV) does not affect behavioral intention (BI) . This can be seen from the value of p-values greater than 0.05 , which is 0.093. If the perceived benefits of the application are high, it will affect users to adopt the mobile banking application. The main purpose of its use is because it is useful in increasing productivity. The results of this study are in line with Pertiwi and Ariyanto (2017), Nugroho et al (2017), Kit et al (2014), Azis and Kamal (2016) and Baptista and Tiago (2015).

Based on the results of the study indicate that hedonic motivation (HM) does not affect behavioral intention (BI) .This can be seen from the value of p-values greater than 0.05, which is 0.198. In a study conducted by Gaitan et al. (2015) stated that hedonic motivation does not affect the behavior intention, technological cases where utilitarian and hedonic benefits exist and both will be very important determinants from the user side, but if the technology is more oriented to hedonic values this will have a greater impact on the intention to adopt it. The results of the study are in line with Azis and Kamal (2016), Gaitan et al (2015), Nugroho et al (2017) and Pertiwi and Ariyanto (2017).

Based on the results of the study show that habit $(\mathrm{H})$ has a significant positive effect on reuse behavior (USE). It can be seen from the value of p-values that are less than 0.05, which is 0.020. The research conducted by Azis and Kamal (2016) in the context of e-commerce, habits are shown to know consumer habits in using the internet to shop online in everyday life. Habit is one of the key constructs and explains the use directly and indirectly through intention to use (Gaitan et al., 2015). This result is in line with the research conducted by Gaitan et al. (2015), Kit et al (2014), Azis and Kamal (2016), Baptista and Tiago, (2016) and Lewis et al (2013).

Based on the results of the study, facilitating codition (FC) has a significant positive effect on reuse behavior (USE. This can be seen from the value of p-values which is less than 0.05 , which is 0.014 . The research conducted by Yu (2012) states that facilitating conditions 
have a positive effect on the behavior of using mobile banking, facilitating conditions are operationalized as the level at which someone believes that he has the context needed to support mobile banking use.The results of this study are in line with Yu, 2012; Nugroho et al., 2017; 2011; and Tarhini et al., 2015).

Based on the results of the study showed that perceived credibility (PC) variable did not affect behavioral intention (BI) variables. This can be seen from the value of p-values greater than 0.05, which is 0.118. According to Arahita and Jurry (2015) in his research stated that perceived credilbility does not affect behavioral intention on mobile BCA, customer perceptions of risk, security and high uncertainties such as data loss and misuse of personal information will be a barrier for customers to reuse BCA mobile. The results of the study are in line with Nugroho et al. (2017), Arahita and Jurry (2015), Karma et al. (2014), Kazi and Mannan (2013) and Safeena et al. (2011).

Based on the results of the study, perceived self-efficacy (PES) does not affect reuse behavior (USE). This can be seen from the value of p-values greater than 0.05 , which is 0.657. The results show that no effect means that without the ability or assistance that is obtained by the surrounding people and others, the customer will still use mobile banking and will use it continuously for banking affairs in his daily life. This is in line with the research conducted by Brown et al (2003).

Based on the results of the study indicate that behavioral intention (BI) has a significant positive effect on reuse behavior (USE). Behavior intention is a factor that reflects the interest in behaving or desires of consumers to behave using or adopting the internet influenced by the conditions of existing facilities and also the habit of using the internet itself (Baptista and Taigan, 2015). This result is in line with the research of Rema and Djoko (2016), Pertiwi and Ariyanto (2017), Yu (2012), Nugroho et al (2017), Abushanab et al (2010), Foon and Fah (2011), Gaitan et al (2015), Kit et al (2014), as well as Azis and Kamal (2016).

\section{CONCLUTION}

The results of the study prove that the research model compiled based on UTAUT2 with modification of the model of the addition of two perceived credibility (PC) and perceived self-efficacy (PSE) explained the behavioral intention (BI) and reuse behavior (USE) of mobile banking applications in Jabodetabek. The results of the significance test on the path of behavioral intention (BI) show that the variable performance expectancy (PE), effort expectancy (EE), social influence (SI), have an influence on behavioral intention (BI). Whereas price / value (PV), hedonic motivation (HM) and perceived credibility (PC) variables have no effect on behavioral intention (BI). The significance test results on the path of reuse behavior (USE) show that habit variables (H), facilitating conditions (FC) and behavioral intention (BI) have an influence on reuse behavior (USE). While the variables perceived self-efficacy (PSE) have no effect on reuse behavior (USE). The recommendation that will be given to the banking sector is to provide mobile banking services by guaranteeing security for the customer related to the risk of the mobile banking application. As well as providing convenience for customers by providing customer service services well in order to serve problems quickly. 
For further research, it is expected that the questionnaire can be spread directly and the respondent accompanied when filling in so that when there are items of questions that cannot be understood by the respondent, they can be explained directly. The number of samples used is expected to be greater and cover all elements of the population. This is done so that the resulting data is more accurate and reflects the actual conditions. For further research, it is expected to add new variables that can influence behavioral intention and reuse behavior) can be added to the next research model and / or include moderator variables that are in accordance with the UTAUT2 model, namely experience, age and gender. This is done to expand the factors that influence the use of a system.

\section{REFERENCES}

Abushanab, Emad, J.Michael Perason and Andrew J.Setterstrom. 2010. Internet Banking and Customers' Acceptance in Jordan: The Unified Model's Perspective. Communications of the Association for Information Systems : Article 26, Volume 26.

Abuzwida, Bashir, Zulkiplie Abd Ghani and Faizal Bin Kasmani. 2017. Study Of Relationship Between Utuat Factors and Intention Towards Usage E-Management In Libyan Petroleum Industry. International Journal of Management, Innovation \& Entrepreneurial Research EISSN: 2395-7662, Vol. 3, No 2, September 2017, pp 61-66.

APJII. 2016. Buletin APJII Edisi 05 November 2016. Access on website APJII : https:// apjii.or.id/content/read/104/275/BULETIN-APJII-EDISI-05---November-2016 /on 25 November 2017.

Arahita, Ceva Lavenja and Jurry Hatammimi. 2015. Factors Affecting the Intention to Reuse. International Journal of Research in Business and Social Science IJRBS ISSN: 21474478 Vol.4 No.4, 2015 Mobile Banking Service.

Azis, Elvira and Ragil Muhammad Kamal. 2016. Adoption of A Consumer Technology Online Shopping with Model MSMEs Unified Theory of Acceptance and Use of Technology 2 .CR Journal Vol.02 No.01

Baptista, Goncalo and Tiago Oliveira. 2015. Understanding mobile banking: The unified theory of acceptance and use of technology combined with cultural moderators. Computers in Human Behavior 50 (2015) 418-430.

Bhimasta, Raden Agoeng .2017. Determinant Factors Of Consumer Adoption Toward Intention To Use Mobile Wallet : A Case Study Indonesian Y Generation. S2 Thesis, UAJY.

Brown, I., C. Zaheeda, D. Douglas, and S. Stroebel. 2003. Cell phone banking: predictors of adoption in South Africa - an exploratory study. International Journal of Information Management, Vol. 23: 381-394.

Foon, Yeoh Sok and Benjain Chan Yin Fah. 2011. Internet Banking Adoption in Kuala Lumpur: An Application of UTAUT Model. International Journal of Business and Management : Vol. 6, No.4. 
Gaitan, Jorge Arenas-Gaitan, Begona Peral-Peral and Maria Angeles Ramon-Jeronimo. 2015. Elderly and Internet Banking: An Application of UTAUT2. Journal of Internet Banking and Commerce, April 2015, vol. 20, no. 1.

Hass, N., and Lehner, F. 2009. Knowledge Management Success Factors - Proposal of an Empirical Research. Proceedings of the 10th European Conference on Knowledge Management.

Jeong , Bong-Keun and Tom E Yoon. 2013. An Empirical Investigation on Consumer Acceptance of Mobile Banking Services. Business and Management Research Vol. 2, No. 1; 2013.

Karma, N.G., Ibrahim, S.B. and Ali, A.H. 2014. Key factors affecting mobile banking adoption among banks' customers in Sudan. International Journal of Liberal Arts and Social Science, 2(6), 112-122.

Kazi, A.K. and Mannan, M.A. 2013. Factors affecting adoption of mobile banking in Pakistan: Empirical Evidence. International Journal of Research in Business and Social Science, 2(3), 54-61.

Kit, A. K., Ni, A. H., Badri, E. N., and Yee, T. K. .2014.. UTAUT2 influencing the behavioural intention to adopt mobile applications .Bachelor Thesis. Universiti Tunku Abdul Rahman.

Laforet, S. and X. Li. 2005. Consumers' attitudes towards online and mobile banking in China. International Journal of Bank Marketing, Vol. 23, No. 5: 362-380, 2005.

Latan, H., and Ghozali, I. 2012. Partial Least Squares: Konsep, Teknik, dan Aplikasi Menggunakan Program SmartPLS 2.0 M3. Semarang: Badan Penerbit Universitas Diponegoro.

Lewis, C. C., Fretwell, C. E., Ryan, J., \& Parham, J. B. 2013. Faculty use of established and emerging technologies in higher education: A unified theory of acceptance and use of technology perspective. International Journal of Higher Education, 2(2), 22-34.

Luarn, P. and H. H. Lin. 2005. Toward an understanding of the behavioral intention to use mobile banking. Computers I Human Behavior, Vol. 21: 873-891.

Magni, Massimo, M. Susan Taylor and Visnawath Venkatesh. 2010. 'To play or not play': A cross-temporal investigation usinh hedonic and instrumental perspective to explain user intentions to explore a technology. Int. J.Human-Computer Studies 68(2010) 572-588.

Mars Indonesia. 2013. Awareness \& Penetrasi Mobile banking Melonjak Tinggi. Access from Website Newsletter Mars Indonesia: http://newsletter.marsindonesia.com/2013/02/06/ awareness-penetrasi-mobile-banking-melonjak-tinggi/ on 11 November 2017.

Nair , Ranjini S. and Shaniba Fasal. 2017. Mobile Banking and its Adopting Challenges. International Journal of Computer Applications (0975 - 8887) Volume 160 - No 4, February 2017.

Natarjan, T., S. A. Balasubrmanian, and S. Manickavasagam. 2010. Customer's choice amongst self service technology (SST) channels in retail banking: A study using analytical hoierarchy process (AHP). Journal of Internet Banking and Commerce, Vol. 15, No. 2: 1-16. 
Nayak, Nitin. Vikas Nath and Nancy Goel. 2014. A Study Of Adoption Behaviour Of Mobile Banking Services By Indian Consumers. International Journal of Research in Engineering \& Technology (IMPACT: IJRET) ISSN(E): 2321-8843; ISSN(P): 2347-4599 Vol. 2, Issue 3, Mar 2014, 209-222.

Nugroho, Priyatmoko, Wing Wahyu Winarmo and Rudy Hartanto.2017. Faktor-Faktor yang Mempengaruhi Niat Menggunakan Mobile payment dengan Pendekatan Extended The Unified Theory of Acceptance and Use of Technology. Jurnal CITEE.

Otoritas Jasa Keuangan (OJK). 2015. Bijak Ber-eBanking. Access on website OJK :

https://www.ojk.go.id/Files/box/buku\%20bijak\%20ber-ebanking.pdf

/on 25 November 2017.

Pertiwi, Ni Wayan Dewi Mas Yogi and Dodik Ariyanto. 2017. Penerapan Model UTAUT2 untuk Menjelaskan Minat dan Perilaku Penggunaan Mobile Banking Di Kota Denpasar. E-Jurnal Akuntansi Universitas Udayana Vol.18.2. Februari (2017): 1369-1397.

Rahmayani, Indah. 2015. Indonesia Raksasa Teknologi Digital Asia. Diakses dari Website Kominfo :https://kominfo.go.id/content/detail/6095/indonesia-raksasa-teknologi-digitalasia/0/sorotan_media pada 11 November 2017.

Rema, Yasinta Oktaviana L. and Djoko Budianto Steyohadi. 2016. Faktor-Faktor yangg Mempengaruhi Penerimaan Mobile Banking Studi Kasus : Bri Cabang Bajawa. Seminar Riset Teknologi Informasi (SRITI).

Riquelme, H. and R. E. Rios. 2010. The moderating effect of gender in the adoption of mobile banking. International Journal of Bank Marketing, Vol. 28, No. 5: 328- Safeena, R., Hundewale, N., dan Kamani, A. 2011. Customer's adoption of mobile commerce: a study on emerging economy. International Journal of e-Education, e-Business, e-Management and e-Learning, 1(3), 228-233.341.

Sripalawat, Jiraporn, Mathupayas Thongmak \& Atcharawan Ngramyarn. 2011. M-Banking in Metropolitan Bangkok and a Comparison with other Countries. Journal of Computer Information Systems, 51:3, 67-76.

Tarhini, Ali, Mazen El-Masri, Maged Ali, and Alan Serrano .2016.Extending the UTAUT model to understand the customers' acceptance and use of internet banking in Lebanon A structural equation modeling approach,. Information Technology \& People, Vol. 29 Iss 4 pp. 830 - 849

Tempo. 2016. Pengguna Mobile Banking di Indonesia Masih Rendah. Access from dari Website Tempo.co : https://bisnis.tempo.co/read/811653/pengguna-mobile-banking-di-indonesiamasih-rendah / on 11 November 2017

Venkantesh, Viswanath, James Y. L. Thong, and Xin Xu. 2012. Consumer Acceptance and Use of Information Technology : Extending The Unified Theory of Acceptance and Use of Technology. MIS Quartely Vol. 36 No.1.

Venkatesh, V., M. G. Morris, G. B. Davis, and F. D. Davis.2003. User acceptance of information technology: Toward a unified view. MIS Quarterly, Vol. 27, No. 3: 425-478, 2003. 
Wang, Y. S., Y. M. Wang, H. H. Lin, and T. I. Tang. 2003. Determinants of user acceptance of Internet banking: an empirical study. International Journal of Service Industry Management, Vol. 14, No. 5: 501-519.

Yu, Chian-So. 2012. Factors Affecting Indivduals to Adopt Mobile Banking Empirical Evidence From the UTAUT Model. Journal of Electronic Commerce Research, Vol. 13, No.2. 